\title{
Effect of Capital Structure on Firms Performance in Nigeria
}

\author{
Asen Ayange ${ }^{1}$, Nwude Chuke Emmanuel ${ }^{1}$, Idamoyibo Hwerien Rosemary ${ }^{2}$, Ufodiama Clifford Ndudi ${ }^{1}$, \\ Udo Emmanuel Samuel ${ }^{1, *}$
}

\author{
${ }^{1}$ Department of Banking and Finance, University of Nigeria Enugu Campus, Nigeria \\ ${ }^{2}$ Department of Accounting, Ignatius Ajuru University of Education, Port Harcourt, Nigeria
}

Received November 10, 2020; Revised December 25, 2020; Accepted January 20, 2021

\section{Cite This Paper in the following Citation Styles}

(a): [1] Asen Ayange, Nwude Chuke Emmanuel, Idamoyibo Hwerien Rosemary, Ufodiama Clifford Ndudi, Udo Emmanuel Samuel, "Effect of Capital Structure on Firms Performance in Nigeria," Universal Journal of Accounting and Finance, Vol. 9, No. 1, pp. 15 - 23, 2021. DOI: 10.13189/ujaf.2021.090102.

(b): Asen Ayange, Nwude Chuke Emmanuel, Idamoyibo Hwerien Rosemary, Ufodiama Clifford Ndudi, Udo Emmanuel Samuel (2021). Effect of Capital Structure on Firms Performance in Nigeria. Universal Journal of Accounting and Finance, 9(1), 15 - 23. DOI: 10.13189/ujaf.2021.090102.

Copyright@2021 by authors, all rights reserved. Authors agree that this article remains permanently open access under the terms of the Creative Commons Attribution License 4.0 International License

\begin{abstract}
The lack of precise methodology to determine the capital structure mix on firm performance has generated a lot of mixed results. Empirical studies from emerging nations revealed a scarcity of empirical findings on the measures with a significant impact on firm performance. This paper examines capital structure measures on manufacturing firm's performance in Nigeria. Using annualized panel data for a sample of 15 quoted firms from diverse sectoral classifications from 1999-2018. Excluding the financial firms due to the uniqueness of their capital structure and the strict legal requirements for their financing choices. This study focus on non-financial firms. Capital structure measures book value and market value of the firm. Results indicate that performance proxy by ROE, and Tobin's Q, significantly influence SDTA, SIZE, LDTA, and TDTA while ROA negatively influences LDTA, D_E, and TDTA. Findings revealed a robust relationship between Tobin's Q and financial performance compared to other book value. Tobin's Q is a better measure of performance within the period under review. The study reveals that Nigerian firms are keenly financed by short - term debt supporting the Pecking Order Theory. It's vital to note that no single theory can sufficiently explain the capital structure effect on firm performance.
\end{abstract}

Keywords Capital Structure, Performance, Manufacturing Companies, Debt, Equity
JEL Classification numbers: G32, L25, L6, N67, G 23, M41

\section{Introduction}

The financial decision of a firm is vital in determining the optimal capital structure mix. Measuring the firm managerial and financial prowess to adjust and direct its numerous leverages to maximize its value, growth, and generate optimum returns. Firms have a diverse level of leverage, the determination of the best mix to enhance performance by managers remains a puzzle to be solved in corporate finance theory and finance literature. The capital structure comprises long-term debt, specific short-term debt, common equity, preferred equity, and retained earnings. Firm performance is calculated by its capacity to generate optimum returns from its assets, maximize the value and wealth of the shareholders. The financing decisions of firms vary according to the rate of risk related to each financing option as well as the relationship between risk and return (Abu-Rub, [1]). Capital structure effect on firm performance varies proportionately in two ways; according to Desai, ([2]) highly leverage firms with similar risk level might have a higher cost of capital and leverage.

Similarly, high financial leverage stirs volatility and 
lower firm values than others as a result of valuation in the capital structure. Modigliani, and Miller, ([3]) assert the irrelevance of the debt-to-equity ratio effect on firm value. The MM model considered the Arrow-Debreu environment of the perfect market condition of no taxes, rational investors, perfect competition, free economy, no bankruptcy costs among others (Hartono, and Utami [4]). According to Modigliani and Miller ([3]), firm's performance is independent of their capital structure; and their financing strategies "equity and debt" are "irrelevant" to the firm's value.

They further upheld that firms at all capital structure levels should maintain the same market value and Weighted Average Cost of Capital (WACC). Empirical findings, on the contrary, argued that the idealistic assumptions are unrealistic and impossible in reality where government taxes are inevitable. Ahmad, Salman, and Shamsi ([5]) observed that imperfect market condition factors group under firm-specific, industry-specific, and country-specific such as firm size, profitability, corporate tax, bankruptcy costs, industry type, and internal policies influences the capital structure decision of a firm (Akeem, Edwin, Kiyanjui and Kayode [6] Dada, and Ghazali [7]). In conceding the tax shield advantage on debt, under imperfect market conditions, Modigliani and Miller ([8]) upheld that a unit increase in firm value increases debt in the capital structure mix where interest payments are tax-deductible to maximize performance and minimizes borrowing cost. Firms enjoy tax shields using more debt under an imperfect market condition. The interest tax shields proposed by Modigliani and Miller, ([8]) are considered irrelevant to the firms with other tax shields, such as depreciation (DeAngelo, Harry, Ronald and Masulis. [9]).

The empirical literature suggests an optimal capital structure that maximizes firm value and simultaneously minimizes the cost of capital, to balance risk and return without a specific methodology to achieve the best mix (Dada, and Ghazali, [7]). Financial theorists, over the decade, tried to provide possible explanations on the financing decisions of firms with diverse and unrealistic assumptions such as the Net Operating Income Approach and the traditional theory. The agency cost theory and pecking order theory among other theories provided a rich understanding of the effect. According to the agency theoretical model popularized by Jensen, and Meckling, ([10]), the capital structure level of a firm minimizes the agency cost and maximizes firm values by trading off agency cost of debt against debt benefit (Riahi - Belkaoui [11] cited in Pirzada, and Bin Mustapha, and Wickramasinghe 12]).

The lack of a precise methodology to determine a firm's optimal capital structure, boost productivity, profitability, growth, stakeholder satisfaction, firm value, minimizes cost, and strike a balance between risk and return is the major problem of this study. Earlier studies are in advanced countries with functional stock markets. In Nigeria and other emerging countries, contemporary studies reveal diverse results on firm Performance as presented in table (1) below. In Palestine [13], India Kannadhasan, ([14]), Pakistan Umar, Tanveer, Aslam, and Sajid, [15], Nigeria Aransiola, and Aransiola ([16]), Nigeria Nwachukwu and Akpeghughu [17] Oil and Gas Companies in Pakistan Raheel, and Shah, F.M [18] Bangladesh Hossain, Imran, and Hossain [19] also observed diverse results as a result of methodology, variable measurement, scope of study, method of data collection among others.

This study differs from previous studies to employ Tobin's Q a measure of market value and accounting value, along with other book value, to examine capital structure on non-financial firm performance which most studies ignored in Nigeria to focus on quoted Banks Nwachukwu and Akpeghughu [17]; Adesina, Nwidobie, and Adesina [20]; Olaniyan, Soetan, and Simon- Oke [21] among others. The contemporary econometric technique (panel data analysis) was also adopted to extend and improve on the other empirical, analysis conducted so far in Nigeria.

The panel data methodology allows for an unbiased and efficient estimation which most studies in Nigeria use the linear regression model predominantly.

\section{Literature Review}

The firm's performance is sizably affected by various factors and capital structure is key among them. Numerous theoretical, and empirical studies conducted to explore possible "positive, negative, or no relationship" between capital structure and firm performance reported mixed results and findings. Similarly, financial theorists tried to propose possible explanations on capital structure effect on firm performance, presenting idealistic assumptions. The Net Income Approach Theory Modigliani and Miller, [8] proposed a positive effect of debt on the firm value. This theory assumes that the cost of debt is less than the cost of equity and that corporate income tax exists. The theory supports $100 \%$ debt finance. The Net Operating Income Approach assumes that the common stock price is not affected by modest or excessive use of debt financing in the operational and business activities of the firm. The firm's value is independent of the weighted average cost of capital and total firm value (Pandey [22]). The assumptions of the Net Income and Net Operating, Income Approach were criticized on the ground of impracticability, artificial, and inadequate (Rezaei, and Ortt, [23]).

The traditional theory hypothesizes that at a minimum level the weighted average cost of capital; a firm optimal capital structure and shareholders' wealth are maximized and achieved. Kraus, and Litzenberger, [24] proposed the 
trade-off theory of optimal capital structure to maximizes firms' value through debt financing to the extent where tax shield is higher than the bankruptcy cost. The trade-off theory allows firms to adopt both debt and equity financing sources notwithstanding their operational cost implication on their operational and business activities. The pecking order theory proposed by Myers, and Majluf, [25], envisages, no optimal leverage due to asymmetric information and transactions costs.

Firms adopt a hierarchical order of available and accessible financing preferences from the least sensitive (least risky) to the most sensitive (most-risky). Thus, firms preferred internal funding over external funding except where internal funds are inadequate or unavailable.

Debt funding is required where external financing is desirable and equity finance becomes the last resort where the desirable is unavailable and inaccessible. The hierarchical order was initiated by Myers, and Majluf, [25] regarding the adverse selection problem of information asymmetric between the managers and outsiders (investors). Pecking order theory proposes that management would at all times prefer equity financing over debt financing in the presence of information asymmetry to reduce transaction costs. By implication, highly profitable firms would prefer internal funding, whereas firms with low profitability tend to employ external financing. The theory hypothesizes a negative relationship between profitability and debt usage. It can be inferred that external financing signifies firm unproductivity and a hostile effect on the stock price as a result of information asymmetry between managers and outsiders (investors). Information asymmetry also occurs when external financing signals a problem that may affect the share price (Frank and Goyal, 26; Kumar, Colombage, and Rao, 27]). The pecking order theory does not envisage the debt ratio (a mix of debt and equity) because of internal and external capital.

Table (1) presents empirical review of studies conducted locally and internationally on capital structure effect on firm performance.

Table 1. Empirical Review

\begin{tabular}{|c|c|c|c|}
\hline Author(s) & Objective & Methodology & Findings/Results \\
\hline \multicolumn{4}{|c|}{ Positive } \\
\hline Le, and Phan [33] & Capital structure and firm performance & Regression & Positive effect on firm performance. \\
\hline $\begin{array}{l}\text { Yinusa, Ismail, Yulia, } \\
\text { and Olawale [34] }\end{array}$ & Capital structure on firm performance & GMM model & $\begin{array}{c}\text { Positive effect on performance where debt } \\
\text { financing is moderately employed in } \\
\text { Nigeria }\end{array}$ \\
\hline $\begin{array}{l}\text { Adesina, Nwidobie, } \\
\text { and Adesina, [20] }\end{array}$ & $\begin{array}{l}\text { Post consolidation capital } \\
\text { structure on the financial performance of } \\
\text { Nigeria quoted banks. }\end{array}$ & Regression & Positive effect on firm performance. \\
\hline Kannadhasan [14] & $\begin{array}{c}\text { Financial leverage on of Pharmaceuticals } \\
\text { companies in India 2000-2012 }\end{array}$ & Panel Data & Positive effect on performance. \\
\hline Vătavu [35] & Capital structure on performance & Regression & Positive effect on performance. \\
\hline \multicolumn{4}{|c|}{ Negative Results } \\
\hline $\begin{array}{c}\text { Ahmed and Amina } \\
\text { [36] }\end{array}$ & $\begin{array}{l}\text { Capital structure on the performance of } \\
\text { non-financial firms in Egypt. }\end{array}$ & OLS Regression & Negative effect on performance \\
\hline $\begin{array}{l}\text { Olaniyan, Soetan, and } \\
\text { Simon- Oke [21] }\end{array}$ & $\begin{array}{l}\text { Capital Structure on Performance of firms } \\
\text { in Nigeria. }\end{array}$ & GMM & Negative effect on performance \\
\hline $\begin{array}{l}\text { Umar, Tanveer, Aslam, } \\
\text { and Sajid, [15] }\end{array}$ & $\begin{array}{l}\text { Debt and equity financing on the } \\
\text { performance of listed firms in Bursa } \\
\text { Malaysia from 2001-2010 }\end{array}$ & Regression & Negative effect on performance \\
\hline $\begin{array}{l}\text { Aransiola, and } \\
\text { Aransiola [16] }\end{array}$ & $\begin{array}{c}\text { Capital structure on the performance of } \\
\text { manufacturing firms in Nigeria }\end{array}$ & Panel Regression & Negative effect on performance \\
\hline Raluca, [37] & $\begin{array}{c}\text { Capital structure on Corporate } \\
\text { performance of listed Romanian } \\
\text { firms }\end{array}$ & Regression & Negative effect on performance \\
\hline \multicolumn{4}{|c|}{ Mixed Results } \\
\hline $\begin{array}{l}\text { Nwachukwu and } \\
\text { Akpeghughu [17] }\end{array}$ & $\begin{array}{l}\text { Capital structure and firms performance in } \\
\text { the Nigerian banking sector }\end{array}$ & Regression & $\begin{array}{l}\text { A positive relationship with equity capital } \\
\text { and a negative relationship with debt } \\
\text { capital and return on investment }\end{array}$ \\
\hline Tianyu, [38] & $\begin{array}{l}\text { Capital structure on performance in both } \\
\text { developed and developing markets }\end{array}$ & Regression & $\begin{array}{l}\text { Negative effect on Chinese firms and a } \\
\text { positive on Germany and Sweden, firms } \\
\text { before the } 2008 \text { financial crisis. }\end{array}$ \\
\hline $\begin{array}{l}\text { Saeedi and Mahmoodi } \\
\text { [39] }\end{array}$ & $\begin{array}{l}\text { Capital structure on performance of listed } \\
\text { firms in the Tehran Stock Exchange }\end{array}$ & Panel Regression & $\begin{array}{c}\text { Capital structure shows a weak-to-no impact } \\
\text { on performance }\end{array}$ \\
\hline \multicolumn{4}{|c|}{ Inconclusive Results } \\
\hline Raheel, and Shah [18] & $\begin{array}{c}\text { Financial leverage on firms' profitability } \\
\text { in Oil and Gas Companies of Pakistan } \\
\text { Listed in KSE }\end{array}$ & $\begin{array}{l}\text { Regression } \\
\text { Analysis }\end{array}$ & $\begin{array}{c}\text { The non-significant effect between financial } \\
\text { leverage and earnings per share. }\end{array}$ \\
\hline
\end{tabular}

Source: Authors Computation (2020). 
The debt ratio represents the accumulated external financial needs of the firm. The theory concentrates on the cost of capital reduction and ongoing performance ignoring the firm's long-term reputation of reliability (regular debt payments), profitability (stable or increasing dividends), and performance. The underpinning theory of this study is the pecking order theory given its relevance in literature. Capital structure effect on firm performance under the perfect market conditions in the United States Petroleum, oil, and electricity industries was examined using the two-stage instrumental variable approach. Findings revealed a non-significant influence on the firm's value. Singh, and Hamid [28] and Singh [29] examined the Western models of capital structure theories in developing nations results revealed a mismatch of funding where long term investments are financed by short term debt. Most firms in developing countries finance their business and operational activities inversely, from the pecking order theorem relying heavily on external financing, the bulk of which is short-term finance (Singh [29]). On the other hand, firms in developing countries rely more heavily on equity issues than those in the developed business climate. Empirical literature acknowledged the long and short-term debt ratio as the best-fit measure of leverage ratios in developing countries like Nigeria. Salawu, [30] observed that $60 \%$ of Nigerian firm's capital structure is short - term debt. Myers [31] observed that only a small proportion of capital formation of US quoted firms are finance externally, equity issues represent a minor percentage while the bulk of external finance is debt. The findings and results vary with publicly quoted firms in Nigeria. The theory of capital structure is closely related to the firm's cost of capital (Nwude, Itiri, Agbadua, and Udeh [32]).

\subsection{Knowledge Gap}

The lack of precise methodology on the determination of the capital structure mix on firm performance has generated a lot of mixed results. Most contemporary empirical studies in Nigeria employed divers leverage measures excluding others; Salawu [30], adopted the short term debt, and excluding total debt to total assets, reporting a negative result. Dada, and Ghazali [7] employed total debt to equity excluding, short term debt to total assets, and long term debt to total assets, short-term debt, long-term debt, and total debt observing a mixed result of a positive and negative relationship while DeAngelo, Harry, Ronald and Masulis [9] employed total debt to equity and long term debt to total assets, excluding short-term debt, and total debt. This study employed Tobin's Q to proxy market value and growth, a leverage ratio of Long Term Debt to total asset, Total Debt to total asset, Short Term Debt to total asset, and Debt equity ratio to cover and expand the frontiers of other empirical analysis in Nigeria. Tobin's Q is a combination of market value and accounting value measuring the firm's value. This study adopts a contemporary econometric technique of (panel data analysis), by using fixed - effect estimation, random - effect estimation, and a pooled regression model with an array of pre-test and diagnostic tests.

\section{Methodology}

The population of this study consists of 102 listed manufacturing firms in the Nigerian Stock Exchange (NSE) as in December 2018. To achieve the study objective, panel data gathered from the annual report of studied firms covering 19 years (1999-2018) of 15 listed firms in all the 7 sectors of Agriculture (FTN Cocoa Processors Plc), Oil and Gas (MRS Oil Nigeria), Basic Material (Meyer and Berger paint), Consumer Goods (Vita foam, Presco and Honey Well), Health Care (Juli Nigeria, Nigeria-German Chemicals), Information, Communication \& Telecoms (Airtel Nigeria, MTN Nigeria) and Industrial Goods (Dangote Cement, Lafarge Africa and UAC of Nigeria) were selected.

For this study, lots of factors were put into consideration in the selection of the sample firms. Such factors highlighted include: firms that were listed in NSE before the year of inception of the study, firms that ceased operation at any point during the period of the study and those that had problems with NSE and Securities and Exchange Commission (SEC) within the period under review were also excluded.

The study adopted the Panel Least Squares models of either the Random Effects Model (Error Component Model) or the Fixed Effect Model (Least Squares Dummy Variable Approach (LSDV) to analyse the effect of capital structure on firm performance in Nigeria. This study excluded the financial companies and the banking sector due to the uniqueness of their capital structure and the strict legal requirements for their financing choices. This study adopted the return on assets (ROA), return on equity (ROE), and Tobin's $\mathrm{Q}$ to measure a firm's performance and Long Term Debt to the total asset (LD/TA), Total Debt to total asset (TD/TA), Short Term Debt to total asset (SD/TA) and Debt equity ratio (D_E) as measures of leverages. Firm size is the controlled variable and is considered to be an important determinant of a firm's profitability.

The functional relationship between firms' performance and capital structure is shown below:

$$
\begin{gathered}
Y_{I T}=\beta_{0}+\beta_{1} X_{i t}+\beta_{2} Z_{i t}+\mu_{i} \\
Y_{i t}=\beta_{0}+\beta_{i}\left(L D T A_{i t}\right)+\beta_{2}\left(T D T A_{i t}\right)+\beta_{3}\left(S D T A_{i t}\right)+ \\
\beta_{4}\left(D E_{i t}\right)+\beta_{5}\left(S I Z E_{i t}\right)+\mu_{i t}
\end{gathered}
$$

\section{Model 1}

$$
\begin{array}{r}
R O A_{i t}=\beta_{0}+\beta_{i}\left(L D T A_{i t}\right)+\beta_{2}\left(T D T A_{i t}\right)+ \\
\beta_{3}\left(S D T A_{i t}\right)+\beta_{4}\left(D E_{i t}\right)+\beta_{5}\left(S I Z E_{i t}\right)+\mu_{i t}(3)
\end{array}
$$


Model 2

$$
\begin{array}{r}
R O E_{i t}= \\
\beta_{0}+\beta_{i}\left(L D T A_{i t}\right)+\beta_{2}\left(T D T A_{i t}\right)+\beta_{3}\left(S D T A_{i t}\right)+ \\
\beta_{4}\left(D E_{i t}\right)+\beta_{5}\left(S I Z E_{i t}\right)+\mu_{i i}
\end{array}
$$

Model 3

$$
\begin{aligned}
& \text { Tobin's } Q_{i t}=\beta_{0}+\beta_{i}\left(\operatorname{LDTA}_{i t}\right)+\beta_{2}\left(T D T A_{i t}\right)+ \\
& \beta_{3}\left(\operatorname{SDTA}_{i t}\right)+\beta_{4}\left(D E_{i t}\right)+\beta_{5}\left(\operatorname{SIZE}_{i t}\right)+\mu_{i t}
\end{aligned}
$$

Where: Yit $=$ Dependent Variables.

$\beta_{0}=$ Intercept of the Equation,

$\beta_{1}=$ Coefficient of $X_{\text {it }}$ Variable.

$\mathrm{X}_{\mathrm{it}}=$ Independent Variable.

$\mathrm{I}=$ (Cross-Sectional Variables) Number of

Manufacturing Firms

$\mathrm{t}=$ Time Period

$\mu=$ Error terms

Estimation Procedure: The estimation processes follow an array of pre-estimation tests, Panel estimation, and diagnostic tests. The unit root test was conducted using the summary method to determine the dataset stationarity.

Estimation Technique: The choice of either pooled Ordinary Least Square (OLS), Fixed Effects, and Random

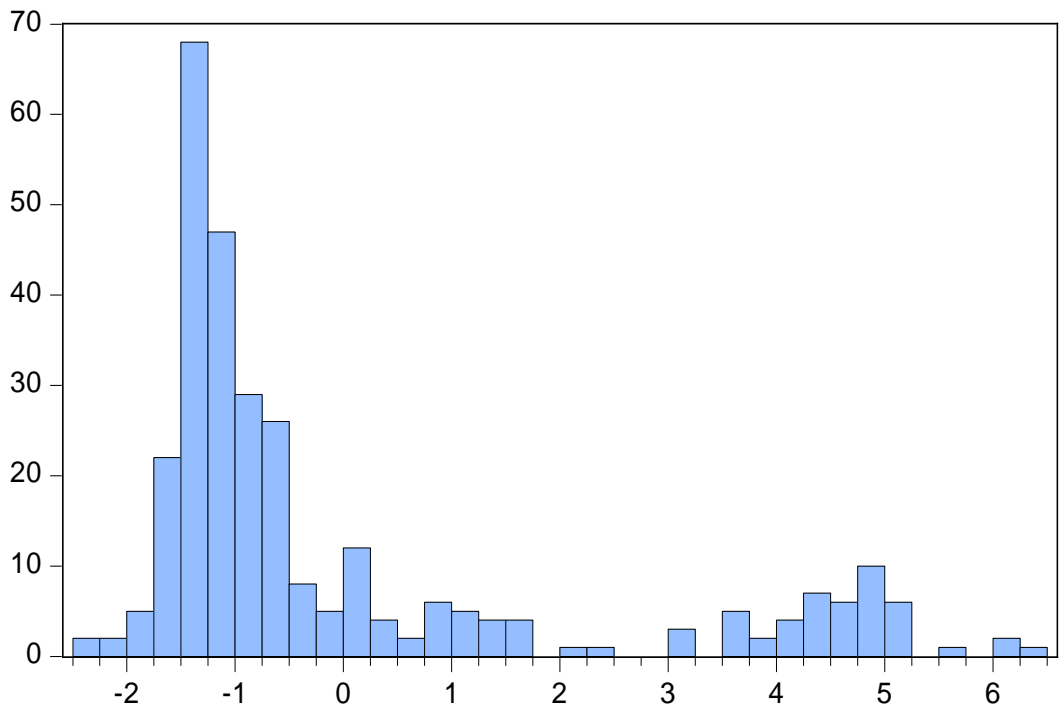

Figure 1. Descriptive Statistics
Effects regression models is dependent on the Hausman Test conducted on the panel regression results.

$$
\begin{gathered}
\text { Hstat }=(\beta F E-\beta R E)^{\prime}[\operatorname{Var}(\beta F E)-\operatorname{Var}(\beta R E)] \\
-1(\beta F E-\beta R E) \sim X 2(k)
\end{gathered}
$$

Large statistic implies that the estimated p-value between the Ho Random Effects (ECM) Error Component Model and the $H_{1}$ the Fixed Effects (LSDV) Least Square Dummy Variable Approach is significant. The $\mathrm{Ho}$ is rejected and $H 1$ is accepted otherwise $H o$ is accepted and $H 1$ is rejected.

\section{Data Analysis and Results: Descriptive Statistic}

\section{Pre-Test}

Figure 1 shows the mean, and median of the series. The standard deviation measures dispersion. Skewness shows the degree of or departure from symmetry and kurtosis the degree of peakedness and Jarque-Bera measure the normality. The results are largely Mesokurtic, the Kurtosis equal (3). By implication, the datasets are normally distributed.

Series: Standardized Residuals

Sample 19992018

Observations 300

Mean $\quad-4.14 \mathrm{e}-16$

Median $\quad-0.917246$

Maximum 6.447188

Minimum $\quad-2.430557$

Std. Dev. $\quad 2.126207$

Skewness 1.528511

Kurtosis $\quad 3.955331$

Jarque-Bera $\quad 128.2254$

Probability $\quad 0.000000$ 
Table 2. Summary of Panel Unit Root Test Results

\begin{tabular}{|c|c|c|c|c|c|c|}
\hline Variables & $\begin{array}{l}\text { Levin, Lin } \\
\text { \&Chut }\end{array}$ & Breitun t-stat & $\begin{array}{c}\text { Im, Pesaran \& } \\
\text { Shin W-stat }\end{array}$ & $\begin{array}{l}\text { ADF-Fisher } \\
\text { Chi-Sq }\end{array}$ & $\begin{array}{c}\text { PP-Fisher } \\
\text { Chi-Sq }\end{array}$ & Status \\
\hline D_E & $\begin{array}{c}34.0423 * * * \\
(0.0000)\end{array}$ & $\begin{array}{c}-7.91893 * * * \\
(0.0000)\end{array}$ & $\begin{array}{c}-7.66577^{* * * *} \\
(0.0000)\end{array}$ & $\begin{array}{c}110.137 * * * \\
(0.0000)\end{array}$ & $\begin{array}{c}250.402 * * * \\
(0.0000)\end{array}$ & $1(0)$ \\
\hline LDTA & $\begin{array}{c}-4.00291^{* * *} \\
(0.0000)\end{array}$ & $\begin{array}{c}-6.80445^{* * *} \\
(0.0000)\end{array}$ & $\begin{array}{c}-5.3681 * * * \\
(0.0000)\end{array}$ & $\begin{array}{c}80.5630^{* * * *} \\
(0.0027)\end{array}$ & $\begin{array}{c}229.044 * * * \\
(0.0002)\end{array}$ & $1(0)$ \\
\hline LOGSIZE & $\begin{array}{c}-4.78906^{* * *} \\
(0.0000)\end{array}$ & $\begin{array}{c}-0.70201^{* * *} \\
(0.2413)\end{array}$ & $\begin{array}{c}-6.51502 * * * \\
(0.0000)\end{array}$ & $\begin{array}{c}97.6679 * * * \\
(0.0000)\end{array}$ & $\begin{array}{c}209.216^{* * *} \\
(0.0000)\end{array}$ & $1(0)$ \\
\hline ROA & $\begin{array}{c}-5.50497 * * * \\
(0.0000)\end{array}$ & $\begin{array}{l}0.77728 \\
(0.7815)\end{array}$ & $\begin{array}{c}-7.42021^{* *} \\
(0.0000)\end{array}$ & $\begin{array}{l}112.351^{*} \\
(0.0000)\end{array}$ & $\begin{array}{c}234.444 * * * \\
(0.0000)\end{array}$ & $1(0)$ \\
\hline ROE & $\begin{array}{c}-14.8383^{* * *} \\
(0.0000)\end{array}$ & $\begin{array}{c}-6.76110^{* * * *} \\
(0.0000)\end{array}$ & $\begin{array}{c}-10.9254^{* *} \\
(0.0000)\end{array}$ & $\begin{array}{c}138.305^{* *} \\
(0.0000)\end{array}$ & $\begin{array}{c}260.685 * * * \\
(0.0000)\end{array}$ & $1(0)$ \\
\hline SDTA & $\begin{array}{c}-5.35865 * * * \\
(0.0000)\end{array}$ & $\begin{array}{c}-5.68768^{*} \\
(0.0000)\end{array}$ & $\begin{array}{c}-7.23945 * * * \\
(0.0000)\end{array}$ & $\begin{array}{c}105.291^{* * *} \\
(0.0000)\end{array}$ & $\begin{array}{c}244.655^{* * *} \\
(0.0000)\end{array}$ & $1(0)$ \\
\hline SIZE & $\begin{array}{l}-2.29973 \\
(0.0107)\end{array}$ & $\begin{array}{c}2.21615^{*} \\
(0.9867)\end{array}$ & $\begin{array}{c}-3.37353^{* * *} \\
(0.0004)\end{array}$ & $\begin{array}{c}68.2886 * * \\
(0.0001)\end{array}$ & $\begin{array}{c}175.752^{* * *} \\
(0.0000)\end{array}$ & $1(0)$ \\
\hline TDTA & $\begin{array}{c}-6.01908^{* * *} \\
(0.0000)\end{array}$ & $\begin{array}{c}-1.76351^{*} \\
(0.0389)\end{array}$ & $\begin{array}{c}-4.46514^{* * *} \\
(0.0000)\end{array}$ & $\begin{array}{c}72.6531^{* * *} \\
(0.0000)\end{array}$ & $\begin{array}{c}215.854 * * * \\
(0.0000)\end{array}$ & $1(0)$ \\
\hline TOB Q & $\begin{array}{c}-6.41906 * * * \\
(0.0000)\end{array}$ & $\begin{array}{c}-1.71783^{* * *} \\
(0.0429)\end{array}$ & $\begin{array}{c}-6.41906 * * * \\
(0.0000)\end{array}$ & $\begin{array}{l}96.7111^{*} \\
(0.0000)\end{array}$ & $\begin{array}{c}186.441 * * * \\
(0.0000)\end{array}$ & $1(0)$ \\
\hline
\end{tabular}

Source: Authors' Computation (2020)

The p-values are smaller than $1 \%$; the null hypothesis is rejected; we conclude that the variables series are stationary.

***, **, * mean significant at $1 \%, 5 \%$ and $10 \%$ respectively. P-Values are in parenthesis. The results depict that all the variables both explanatory and control variables are stationary at level.

\subsection{Unit Root Test}

The summary methods of Levin, Lin, Chu [40] (assuming common unit root process), Im, Pesaran and Shin W-stat, Augmented Dickey-Fuller test (ADF), and PP-Fisher Chi-square panel unit root tests were employed to examine the stationarity properties of the variables for a meaningful analysis.

\subsection{Panel Regression Analysis}

\section{Model 1: Capital structure correlates with return on assets of manufacturing firms in Nigeria}

The Hausman test was adopted to select the best fit model to test the hypothesis; the Cross-Section chi-square statistic with 5 degrees of freedom is 2.80 and the p-value of 0.7305 is presented in Table 3 below. The P-value of the Haussmann Chi-square Statistic is greater than $5 \%$. The null hypothesis is accepted (random effect).

Table 3. Capital Structure Versus Return on Assets of Manufacturing Firms in Nigeria

\begin{tabular}{ccccc}
\hline Variable & Coefficient & Std. Error & t-Statistic & Prob. \\
C & 284.340 & 114.730 & 2.478 & 0.0138 \\
LDTA & -17.463 & 10.501 & 1.662 & 0.0000 \\
D_E & -29.678 & 7.485 & -3.964 & 0.0001 \\
LOGSIZE & 21.032 & 7.603 & -2.766 & 0.0060 \\
SDTA & 96.198 & 8.036 & 11.969 & 0.0000 \\
TDTA & -10.116 & 2.912 & -0.040 & 0.0001 \\
\multicolumn{5}{c}{ Effects Specification } \\
R ${ }^{2}$ & 0.66 & Hausman & \\
Adjusted & 0.63 & Test & \\
R-squared & 28.80 & \\
F.Stat. & 28.87 & P-value & 0.7305 & \\
P-value & 0.0000 & D.W stat & 1.902 & \\
\hline
\end{tabular}

Source: Authors' Computation (2020)

Table (3): The $\mathrm{R}^{2}$ of $66 \%$ shows, the goodness of the panel regression. The exogenous variables are jointly responsible for a $66 \%$ variation in the endogenous variable with an unexplained variation of $34 \%$. Firm performance proxy by return on asset indicate a negative and significant relationship between long term debt, debt-equity, and total debt. The overall panel regression results are significant. F-stat of (28.87) is associated with a P-value of $(0.000)$. The result is reliable for a meaningful analysis. The Durbin Watson Statistics of 1.90 is approximately 2 ruling out all possible suspicion of first-order positive autocorrelation.

\section{Model 2: Capital structure correlates with return on equity of manufacturing firms in Nigeria}

The Hausman test was adopted to select the best fit model to test hypothesis two; the Cross-Section chi-square statistic with 5 degrees of freedom is 1.761 and the p-value of 0.881 is presented in Table 4 below. The P-value of the Haussmann Chi-square Statistic is greater than 5\%. The null hypothesis is accepted (random effect) following the standard null hypothesis.

Table 4. Capital Structure Versus Return on Equity of Manufacturing Firms in Nigeria

\begin{tabular}{ccccc}
\hline Variable & Coefficient & Std. Error & t-Statistic & Prob. \\
\hline C & 2.649 & 1.802 & 1.469 & 0.1427 \\
D_E & -0.185 & 0.148 & -1.2467 & 0.0001 \\
LOGSIZE & 0.008 & 0.1185 & 0.069 & 0.0002 \\
LDTA & 0.399 & 0.181 & 2.202 & 0.0285 \\
SDTA & 0.535 & 0.162 & -3.294 & 0.0001 \\
TDTA & 0.136 & 0.062 & -2.170 & 0.0001 \\
\multicolumn{5}{c}{ Effects Specification } \\
R $^{2}$ & 0.87 & Hausman \\
F.Stat. & 3.407 & Test & 1.761 \\
P-value & 0.0000 & D.value & 0.881 \\
\hline
\end{tabular}

Source: Authors' Computation (2020) 
Table (4): The $\mathrm{R}^{2}$ of $87 \%$ shows, the goodness of the panel regression model. The exogenous variables are jointly responsible for an $87 \%$ variation in the endogenous variable with an unexplained variation of $13 \%$. Firm performance proxy by return on equity showed a positive and significant relationship with firm size, LDTA, SDTA, and TDTA and a negative relationship with ROE under the measure of D_E. The overall panel regression results are significant. F-stat of (3.407) associated with the $\mathrm{P}$-value of (0.000). The result is reliable for a meaningful analysis. The Durbin Watson Statistics of 2.161 rules out all possible suspicion of first-order positive autocorrelation

\section{Model 3: Capital structure correlates with a market value of manufacturing firms in Nigeria}

The Hausman test was adopted to select the best fit model to test hypothesis three; the Cross-Section chi-square statistic with 5 degrees of freedom is 6.773 and the p-value of 0.238 is presented in Table 5 below. The P-value of the Haussmann Chi-square Statistic is greater than $5 \%$. The null hypothesis accepted (random effect) is preferable over the fixed effect following the standard null hypothesis.

Table 5. Capital Structure Versus Market Value of Manufacturing Firms in Nigeria

\begin{tabular}{ccccc}
\hline Variable & Coefficient & Std. Error & t-Statistic & Prob. \\
\hline C & 0.263 & 0.876 & 0.300 & 0.7639 \\
TDTA & -0.027 & 0.022 & -1.246 & 0.0011 \\
SDTA & 0.091 & 0.061 & 1.487 & 0.1380 \\
LOGSIZE & 0.087 & 0.058 & 1.505 & 0.1333 \\
LDTA & -0.212 & 0.080 & -2.647 & 0.0086 \\
D_E & 0.0056 & 0.057 & 0.098 & 0.9220 \\
\multicolumn{2}{c}{ Effects } & Specification & & \\
R & 0.68 & Hausman & Test & \\
F.Stat. & 12.925 & P-value & \multicolumn{2}{c}{0.238} \\
P-value & 0.0000 & D.W stat & \multicolumn{2}{c}{2.108} \\
\hline
\end{tabular}

Source: Authors' Computation (2020)

Table (5): The $\mathrm{R}^{2}$ of $68 \%$ shows, the goodness of the panel regression model. The exogenous variables are jointly responsible for a $68 \%$ variation in the endogenous variable with an unexplained variation of $32 \%$. The overall panel regression model result is significant. F-stat of (12.925) is associated with the P-value of (0.000). The result is reliable for a meaningful analysis. The Durbin Watson Statistics of 2.108 rules out all possible suspicion of first-order positive autocorrelation.

\section{Discussion}

The results in model (1) of table (3) reveal a negative and significant relationship between LDTA, D_E, and TDTA on the performance level of studied firms by $17.46 \%, 29.67 \%$, and $10.11 \%$ respectively. Supporting the pecking order theory hypothesizes a negative relationship between profitability and debt usage. [41;42] argued that long - term debt increases a firm's value, due to a lower long - term debt ratio in the capital structure of companies. Highly profitable Nigerian firms require less debt finance. On the other hand, a positive and significant relationship was observed between short-term debt leverage ratio, ROA, and ROE supporting the agency cost model of debt ratios as a disciplinary device to reduce cash flow waste mitigating the opportunistic behaviours of shareholders-managers to generate sufficient cash flow to prevent liquidation. The result correlates with the true nature of the Nigerian business climate where the majority of firms depend on short-term financing from deposit money banks as a result of the high cost of raising equity from the stock market and debt market underdevelopment. The findings are consistent with the finding of (Nwachukwu and Akpeghughu 17; Hossain, Imran, \& Hossain 19]).

A positive and significant correlation was reported between TDTA, LTDTA, STDTA, and ROE. A unit increase influences manufacturing firm performance in model (2) of table (4). In model 3 of table (5) the results show a positive and significant relationship between market value measured by (Tobin Q) and SDTA, LDTA, D_E. A negative relationship with TDTA was also reported. The control variable of firm size reveals a strong significant effect on firm performance and market value measured by Tobin $\mathrm{Q}$. The significance of a firm's size on performance indicates that large firms earn higher returns compared to smaller firms, presumably as a result of diversification of investment and economies of scale. Total debt shows a negative and significant relationship with the firm market value. It can be inferred that a unit increase in total debt decreases the firm market value. The findings substantiate the findings and results of (Umar, Tanveer, Z., Aslam, S.,and Sajid 15; Akguc, , Choi,.. Kim, and McKenzie, 43; Aransiola, and Aransiola 16; Ardalan,44]) and others.

\section{Conclusions}

The results and findings of this study revealed a disparity between the capital structure of firms in an emerging business climate like Nigeria and those in the developed nations. Manufacturing firms in Nigeria prefer and rely heavily on short-term debt rather than long-term financing. Firm-specific factors that are relevant in the developed business climate are also relevant in Nigeria in explaining the capital structure and corporate performance. Overall, empirical results support the pecking order and agency cost theories of capital structure. 
The findings limit the explanatory power of the capital structure theories in Nigeria showing that the theoretical underpinnings are still largely unresolved.

It's vital to note that no single theory can sufficiently explain the relationship between capital structure and firm performance. Theories are based on critical assumptions ignoring the extremely diversified and complex realities in the economic and business climate.

\section{Acknowledgment}

The author confirms that the data do not contain any conflict of interest.

\section{REFERENCES}

[1] Abu-Rub, N. Capital Structure and Firm Performance: Evidence from Palestine Stock Exchange. Journal of Money, Investment and Banking, 23(1): pp 109-117, 2012.https://doi.org/10.13189/jmib.2012.091201.

[2] Desai, A. "Corporate Tax Avoidance and Firm Value." Harvard University and NBER, 2007

[3] Modigliani, F., Miller, M. "The cost of capital, corporation finance and the theory of investment." American Economic Review, 48, pp 261- 297, 1958. DOI:28.1278/AER.1958.80 9421.

[4] Hartono, G. C, Utami, S. R. The Comparison of Sustainable Growth Rate, Firm's Performance, and Value Among the Firms in Sri Kehati Index and Idx30 Index in Indonesia Stock Exchange, International Journal of Advanced Research in Management and Social Sciences, 5. (5) pp 130-146, 2016. https://doi.org/10.970/53-07040323.

[5] Ahmad, N., Salman, A., Shamsi, A. F. (2015). Impact of Financial Leverage on Firms' Profitability: An Investigation from Cement Sector of Pakistan, Research Journal of Finance and Accounting,.6, (7). Pp 59-70, 2015. DOI:29.14818/RJFA.59.7944271.

[6] Akeem, B, L., Edwin, T, K., Kiyanjui M., W., Kayode, M, K., (2014). Effects of Capital Structure on Firm's Performance: Empirical Study of Manufacturing Companies in Nigeria. Journal of Finance and Investment Analysis, vol. 3, No.4, 2014, 39-57, 2014. https://doi.org/3.9739/2014-403 303957.

[7] Dada, A. O., \& Ghazali, Z. (2016). The Impact of Capital Structure on Firm Performance: Empirical Evidence from Nigeria. Journal of Economics and Finance, 7(4), 23-30, 2016. https://doi.org/10.9790/5933-0704032330

[8] Modigliani, F., \& Miller, M., (1963). Corporate Income Taxes and Cost of Capital: A Correction. American Economic Review 53, 433-443, 1963.

[9] DeAngelo, Harry, \& Ronald W. Masulis. 1980. Optimal Capital Structure under Corporate and Personal Taxation. Journal of Financial Economics 8, No 1, 3-29, 1980.

[10] Jensen, M., \& Meckling, W. (1976). "Theory of the firm:
Managerial behavior, agency costs, and ownership structure". Journal of Financial Economics, 3, 305-360, 1976.

[11] Riahi - Belkaoui, A. (1999), Capital Structure: Determination, Evaluation, and Accounting, Quorum Books Publisher, Westport, CT. 1999.

[12] Pirzada, K., Bin Mustapha, M. Z., Wickramasinghe, D. Firm Performance, Institutional Ownership, and Capital Structure: A Case of Malaysia. Global Conference on Business and Social Science. 4 N0 3 pp 39-50, 2015. https://doi.org/10.1016/j.sbspro.2015.11.025

[13] Aburub, N. Capital Structure and Firm Performance: Evidence from Palestine Stock Exchange. Journal of Money, Investment and Banking, 23 (9), 2016 pp 109-117. https://doi.org/11.346/jmib.2016.23.09510

[14] Kannadhasan, M, A, S. Relationships among business strategy, environmental uncertainty, and performance of firms operating in the transport equipment industry in India. Journal of Emerging Capital Market 3(2).. pp24.38.2016.https://doi.org/10.1016/jecm.2016.3.02.5243 8.

[15] Umar, M., Tanveer, Z., Aslam, S., Sajid, M. Impact of capital structure on firms' financial performance: Evidence from Pakistan. Research Journal of Finance and Accounting, 3 (9): 1- 12. 2012. https://doi.org/24.60/rjfa.2012.12.19405.

[16] Aransiola, S. Y., Aransiola, O. Capital structure and profitability: a critical analysis of quoted manufacturing companies in Nigeria. American Journal of Economics, Finance, and Management, 1(5), 369-376. 2015.https://doi. org/1.5/ajefm.2015.369.376.

[17] Nwachukwu U, Akpeghughu MK (2016). Effect of capital structure on firm performance (A Study of Selected Quoted Banks in Nigerian Stock Exchange). International Journal of Business Management. 4, No3: 114-122.2016.Doi.10.101 6/JBM.2016.114.10252.

[18] Raheel, T., Shah, F.M. A Study That Identifies the Relationship between the Financial Leverage and Firms Profitability: Empirical Evidence from Oil and Gas Companies of Pakistan Listed In KSE, International Journal of Scientific \& Engineering Research, 6, (11) 20-34, 2016. Doi.10.1016/jser.2016.611.02034.

[19] Hossain, Md. Imran, Hossain Akram. Determinants of capital structure and testing of theories: A study on the listed manufacturing companies in Bangladesh. International Journal of Economics and Finance 7: No6, 176-185. 2015. Doi.10.1016/JEF2015.7.6176.1852015.

[20] Adesina, J, B, Nwidobie, B, M, \& Adesina, O, O. Capital structure and financial performance in Nigeria. International Journal of Business and Social Research 5: No2 21-31. 2015. Doi.10.1016/JBSR.2015.4.2.21.312015.

[21] Olaniyan, O, Soetan, R, Simon- Oke, O Capital Structure-Firm Performance Relationship: Empirical Evidence from African Countries. Journal of Emerging Trends in Economics and Management Sciences (JETEMS) 8(2):82-95, 2017. Doi.10.1016/JETEMS.2017.8.282952017.

[22] Pandey, I. M. Financial Management, Vikas Publishing House, New Delhi. 1999

[23] Rezaei, J., Ortt, R. Entrepreneurial orientation and firm 
performance: the mediating role of functional performances. Management Research Review, 41(7), 878-900. 2018. https://doi.org/10.1108/MRR-03-2017-0092

[24] Kraus, A. Litzenberger, R. A state preference model of optimal financial leverage, The Journal of Finance, 28, 911-921. 1973

[25] Myers, S. C. Majluf, N.S. Corporate Financing and Investment Decisions when Firms have Information that Investors do not have”, Journal of Financial Economics, Vol. 13, pp. 187- 221. 1984.

[26] Frank M, Goyal, V. Testing the pecking order theory of capital structure, Journal of Financial Economics, 67: 217-248.2003.Doi.10.1016/JFE.2003.67:217-2003.

[27] Kumar, S., Colombage, S., Rao, P. Research on capital structure determinants: a review and future directions. International Journal of Managerial Finance, 13(2), 106-132. 2017. Doi.10.1016/JBM.2016.114.10252.

[28] Singh, A., Hamid J. 'Corporate Financial Structures in Developing Countries', International Finance Corporation Technical Paper, No. 1, Washington DC. 1992.

[29] Singh, A. 'Corporate Financial Patterns in Industrializing Economies: A Comparative Study', International Finance Corporation Technical Paper, No. 2, Washington DC.1995

[30] Salawu, R. O. 'An Empirical Analysis of the Capital Structure of Selected Quoted Companies in Nigeria', The International Journal of Applied Economics and Finance, Vol. 1, No. 1, pp. 16-28.2007. Doi.10.1016/IJAE2007.16.2 8.2007.

[31] Myers, S. C., 'Capital Structure’, The Journal of Economic Perspective, Vol. 15, No. 2, pp. 81-102.2001.

[32] Nwude, Itiri, Agbadua, Udeh. Impact of Debt Structure on frim performance; empirical evidence from Nigerian quoted firms. Asian Economic and Financial Review, 2016, 6(11):647-660. 20Doi.645.6/AEFR.2016.114.10252.

[33] Le, T. P. Phan, T. B. N. Capital structure and firm performance: Empirical evidence from a small transition country. The Journal of Research in International Business and Finance, 42: 710-726. (2017). Doi.10.1016/JRIBF.201 7.710-726.
[34] Yinusa, O, G, Ismail, A, Yulia, R, Olawale, L, S. Capital Structure and Firm Performance in Nigeria. African Journal of Economic Review, 6 (1) 31- 56.2019.Doi.10.1016/AJER. 2019.6.31.2019.

[35] Vătavu, S. The impact of capital structure on financial performance in Romanian listed companies. Procedia Economics and Finance, 32: 1314-1322. 2015.

[36] Ahmed, Amina. Impact of Capital Structure on Firm's Performance: Focusing on Non-Financial Listed Egyptian Firms. International Journal of Financial Research. 10 (6) 78-87 2019. Doi.02019/IJER.2019.078.0872019.

[37] Raluca. Capital structure and corporate performance of Romanian listed companies. International Journal of Academic Research Account, Finance, and Management Science 4: 287-292. 2014.

[38] Tianyu, H. The comparison of impact from capital structure to corporate performance between Chinese and European listed firms. Master's thesis at Jonkoping University. 2016.

[39] Saeedi A, Mahmoodi I. Capital structure and firm performance: evidence from Iranian Companies, International Research Journal of Economics. 9 (7) 1-26 2011. Doi.01216/IRJE.2011.9.7.010262.

[40] Levin, A., C. F. Lin, Chu C. "Unit Root Tests in Panel Data: Asymptotic and Finite-Sample Properties," Journal of Econometrics, 108, 1-24. 2002.

[41] Brick, I. E. Ravid, 'On the Relevance of Debt Maturity Structure’, Journal of Finance, Vol. 40, pp. 1423-37. 1985

[42] Igbinosa, S. Another look at the capital structure and corporate performance in emerging markets: The case of Nigeria. Asian Journal of Business Management, 7(1), 1-12.2015. Doi.10.1016/JBM.2016.114.10252.

[43] Akguc, S., Choi, J. J., Kim, S. J., McKenzie, M, Do private firms perform better than public firms. 10th Annual Conference on Asia-Pacific Financial Markets CAFM of the Korean Securities Association KSA. 2015

[44] Ardalan, K. Capital structure theory: Reconsidered. Research in International Business and Finance, 39: 696-710. 2017. 